\title{
Positron Emission Tomography
}

中井義 明*

1. PET (Positron Emission Tomography) とは PETは陽電子(ポジトロン)を放出するアイソトープ(ポジトロ ン放出核種)で標識された薬郕を生体に投与し,その体内での分 布をPET 装置を用いて画像化する検査法である.

自然に存在する炭素原子 $\left({ }^{12} \mathrm{C}\right)$ の原子核の大部分は陽子6個と 中性子 6 個とから構成されている.これに対し自然には存在し ないが小型のサイクロトロンを使用して加速した高エネルギー の陽子 ${ }^{14} \mathrm{~N}$ に照射すると陽子 6 個と中性子 5 個からなる ${ }^{11} \mathrm{C}$ を 製造する事ができる.(図1)このアイソトープは非常に不安定で

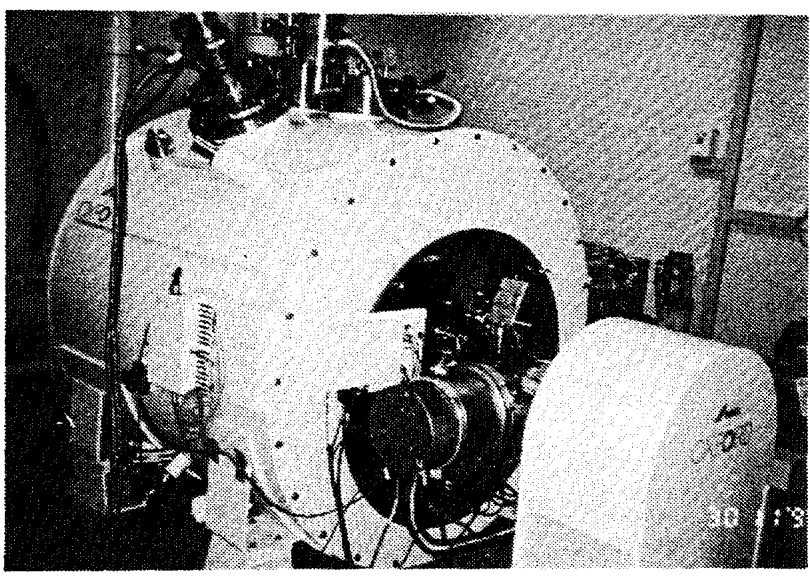

図 1.サイクロトロン

原子核の 1 個がこわれてポジトロンを放出して中性子に変わ り，陽子 5 個と中性子 6 個の原子核を持つ安定な ${ }^{11} \mathrm{~B}$ になる。 この際に放出されるポジトロンは普通の電子と質量は同じであ るが電子とは反対の正の電荷をもっている。このポジトロンは すぐに負の電荷を持っている電子と結合し2本の光子(5llkeV $\gamma$ 線)を反対方向に放出して消滅する.(図 2)この一対の光子を PET 装置を用いて測定することにより ${ }^{11} \mathrm{C}$ などのポジトロン核 種の体内での存在分布を定量的に正確に画像化することができ

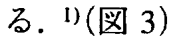

\footnotetext{
1997 年 5 月 7 日受付

*大阪市立大学医学部 耳鼻㸶喉科学教室

于 545 大阪府大阪市阿㥉野区旭町 1-5-7
}

キーワード：ポジトロン放出核種(Radionuclide), PET(PET), SPECT (SPECT)，FDG-PET(FDG-PET)，腫瘍 (tumor)

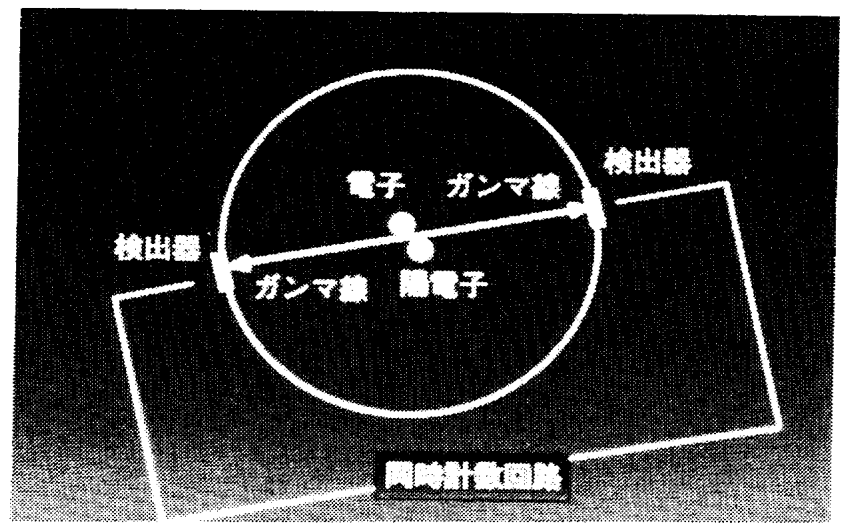

図2. ポジトロンCTの原理

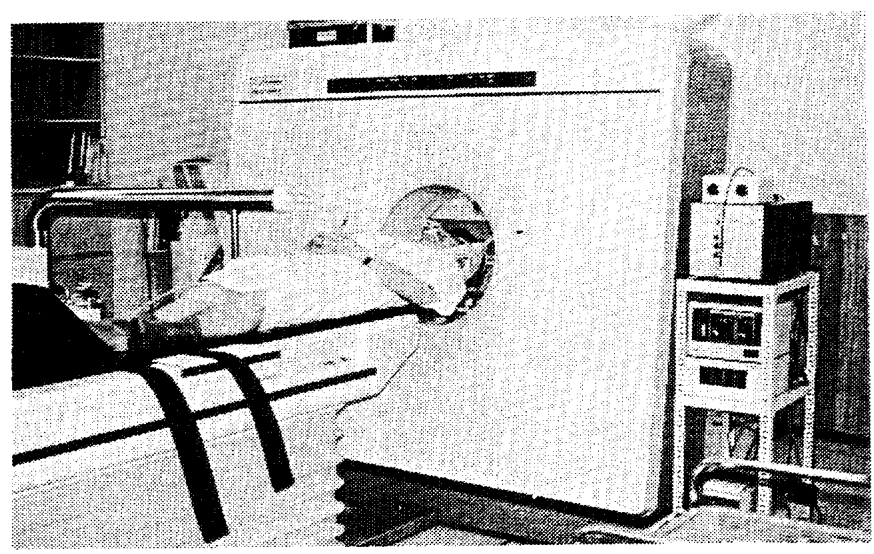

図 3. PET 装置

\section{2. ポジトロン放出核種の種類}

小型のサイクロトロンを用いて作成されるポジトロンを放出 する放射性同位元素には炭素 $-11\left({ }^{11} \mathrm{C}\right)$, 窒素 $-13\left({ }^{13} \mathrm{~N}\right)$, 酸素 -15 $\left.{ }^{(15} \mathrm{O}\right)$, フッ素-18 $\left.{ }^{18} \mathrm{~F}\right)$ がある. その半隇期は一般に短く ${ }^{11} \mathrm{C} 20$ 分, ${ }^{13} \mathrm{~N} 10$ 分, ${ }^{15} \mathrm{O} 2$ 分, ${ }^{18} \mathrm{~F} 110$ 分である.

一方ジェネレーターを利用して産生されるポジトロン放出核 種には銅 $-62\left({ }^{62} \mathrm{Cu}\right)$, ガリウム $-68\left({ }^{(68} \mathrm{Ga}\right)$, ルビジウム $-82\left({ }^{82} \mathrm{Rb}\right)$ などがあり, 各各半隇期は 10 分, 68 分, 75 秒である.

これらは目的に応じて種々の化合物に標識されPET検査に用 いられている.

\section{PET が特に利用される領域}

脳においては血液量, 酸素消費量, ブドウ糖消費量が計測さ れ, 種々の脳疾患, 動脈閉塞症, 中枢神経変性疾患などの早期 診断，手術適応などに威力を発揮している. 
心臓ではブドウ糖代謝をみる事により軽度の虚血性疾患も正 確に診断できる。

悪性腫瘍ではグルコース代謝, 核酸代謝, アミノ酸代謝など が充進しているのでこれらのポジトロン標識化合物を使用して その評価が行われる.現在この目的で使用されている主なポジ トロン標識薬剤には, ${ }^{18} \mathrm{~F}$-fluorodeoxyglucose, ${ }^{11} \mathrm{C}$-L-methionine, ${ }^{18} \mathrm{~N}$-tyrosine, ${ }^{13} \mathrm{~N}$-glutamate, ${ }^{18} \mathrm{~F}$-fluorophenylalanine, ${ }^{11} \mathrm{C}$ thymidine, ${ }^{18} \mathrm{~F}$-fluorodeoxyuridine などがある. ${ }^{2)}($ 表 1)

表 1. 腫瘍診断と使用される放射性薬物 (Straus, LGら，1991による)

Radiopharmaceutical

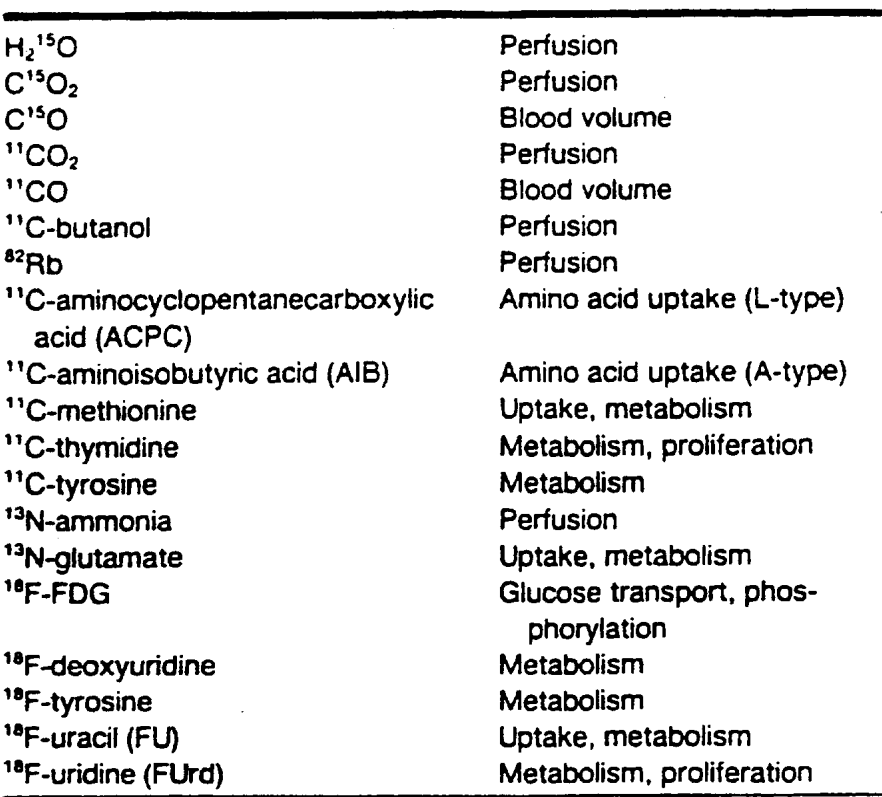

\section{4. クリニカル PET の特徵}

腫瘍核医学検査には従来よりガリウムシンチが広く用いられ ている. 機器の性能向上, SPECT(Single Photon Emission CT)の 導入により診断能は向上している. SPECT に比し PET には次 の特徽がある. 1) 感度は $20 \sim 50$ 倍も高く, 空間分解能も 3 5 倍優れている.2)定量性がより高い.3) ポジトロン放出核種 の半減期が非常に短いので被験者の放射線被爆が少ない.4)利 用するアイソトープは水, 酸素, グルコース,アミノ酸など生 体内の生理的, 生化学的に重要な物質を直接標識して検査に使 用可能である.

\section{5. 腫瘍の代謝の評価}

腫瘍核医学検査の役割は，1）早期診断，2）良性，悪性の鑑別 診断，3）病巣の広がり及びその転移病巣の検出，4）治療方針の 決定, 5) 治療効果の判定, 6) 予後の判定, 7)経過観察などであ る.PET は前述の如く分解能が高く, 定量性も優れており小病 巣の検出も可能で早期診断にもつながる. 過去各PET施設から 報告されている様に当院でも舌癌や肺癌のリンパ節転移でX線 CT MRI で検出されていない小病巣がPET でとらえられて いる。一報頭䅡部悪性腫湯の X 線 CT や MRI 像による治療後 の陰影に対して悪性像が消失しているか否かをPETにより判定
することができる， ${ }^{3,4)}$

悪性腫瘍の代謝の評価に最も良く使用されているのは 18F2fluoro-2-deoxy-D-glucose (FDG)である. FDG はグルコースの類 似化合物であり腫瘍内に移行し hexokinase によりリン酸化され るが次の代謝段階である phosphohexoseisomerase の基質とはな らないためそれから先へは代謝されず組織内に蓄積される.

FDG-PETでは動脈採血せずに非侵襲的に定量的評価を行うた めの一つの手段として, 病変部の ROIの放射能を投与量と体重 で補正した定量的数值を用いた評価があり ${ }^{5)}$ ，実際の診療にお いて有用なことがよく知られている。この数值は standardized uptake value (SUV), differentaial absorption ratio(DAR), distribution uptake ratio(DUR) などと表現され同義に用いられている.一 般には FDG 静注後, 1 時間前後の測定值が用いられ，悪性腫瘍 では高值を示し，良性腫瘍では低值を示すとされている 2)。 た腫瘍部の放射能の経時的変化は，悪性腫泀では上昇し続け， 良性疾患では静注後早期にプラトーに達したり, ピークに達し たのち下降傾向を示すことが多い. ${ }^{699)}$ (time activity curve : TAC)

現在この FDG は脳, 心臓においてもグルコース代謝の評価 に広く利用されている。次に私共が主に検討してきた頭䅡部腫 瘍の良性, 悪性, 進展度の診断, 治療効果及び予後の判定など を紹介する。

\section{6 . 頭頝部腫瘍に対する FDG-PET}

舌, 上顎, 上咽頭の悪性腫瘍及び上顎, 耳下線の良性腫瘍一 部炎症の 17 症例について検査を行なった. 各症例にFDG185 $370 \mathrm{MBq}$ の静注を行ない $5,10,20,30,40,55$ 分後に観察し た. 55 分後に投与量に対する組織内濃度の率(differential absorption raios : DAR）を視覚による色の濃度の判定とともに算出した. 同時に静注後各時間の組織内への移行率を測定しその移行速度 (time activity curve : TAC) を検討した。

結果，悪性腫湯は全例周囲組織よりも高い集積が見られた。 DAR は 11 症例で $4.9 \sim 11.0$ (平均 8.3)TAC は強い上昇カーブ を示した. 6例の良性腫瘍及び炎症ではDAR2.2〜4.2(平均 3.1) TACは中等度の上昇カーブあるいは平坦カーブを示した. 悪性 腫瘍は放射線, 化学療法後は DAR は低下し, TAC は中等度上 昇あるいは平坦カーブに移行しその治療効果判定はCT, MRI像 に比し非常に有用であった（図 4,5)図 6〜8に上咽頭癌症 例，鼻副亩腔パピローマの症例を示す.

\section{PET の将来}

本邦で PET が稼働しているのは約 20 施設である。これには サイクロトロンや薬剤合成装置などが必要であるため将来も限 られた施設でしか行なわれない可能性が高い. 当院の現状では ガリウムシンチや超音波，X線 CT, MRI などで異常のある症 例を選んでPET検査を行なっているが精度が良く短時間で全身 の検索が可能であるので, 装置が安価になれば各PET施設に複 数台の装置を設置され，これによる腫瘍核医学は飛躍的に発展 すると期待される. 現在数施設で高度先端医療が始められた段 階であるが高額の検査料が保険診療として認定される事も腫瘍 患者への最新の検査手段として必要である. 


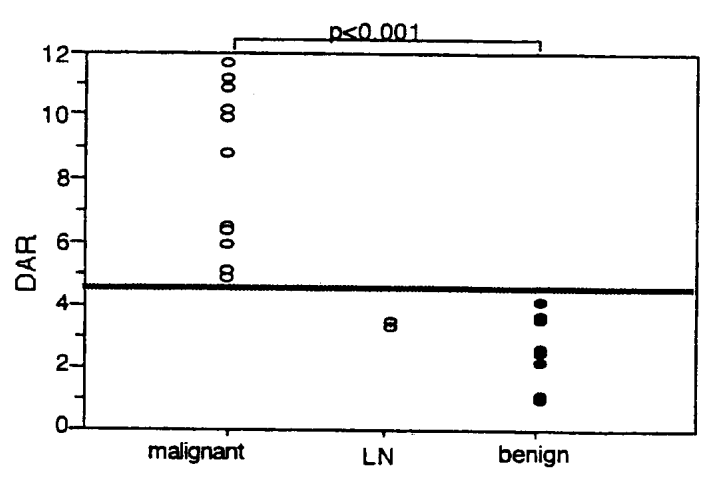

図 4. 悪性腫堭 (malignant) リンパ節 (LN) 良性腫瘍 (benign)の differential absorption raio(DAR). 悪性腫瘍のDARは良 性腫瘍よりも高値を示す。

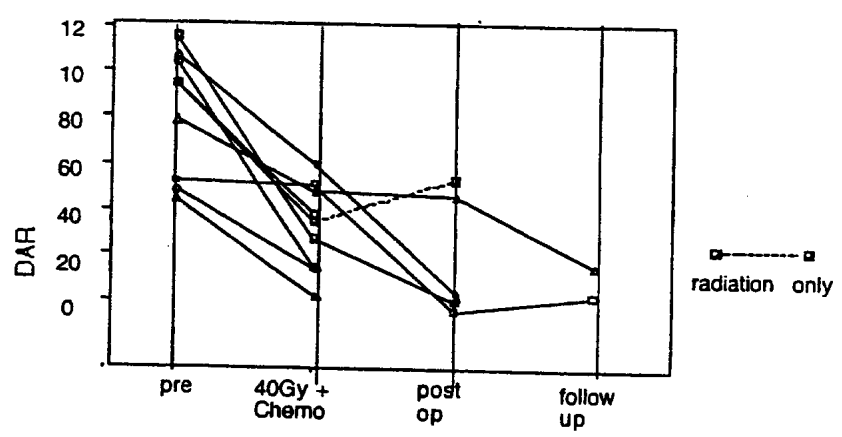

図 5. 悪性腫瘍に対する治療の効果を DARで示す，pre：治 療前, $40 \mathrm{~Gy}+$ chemo : 40Gy. 術前照射と化学療法, post op : 術後

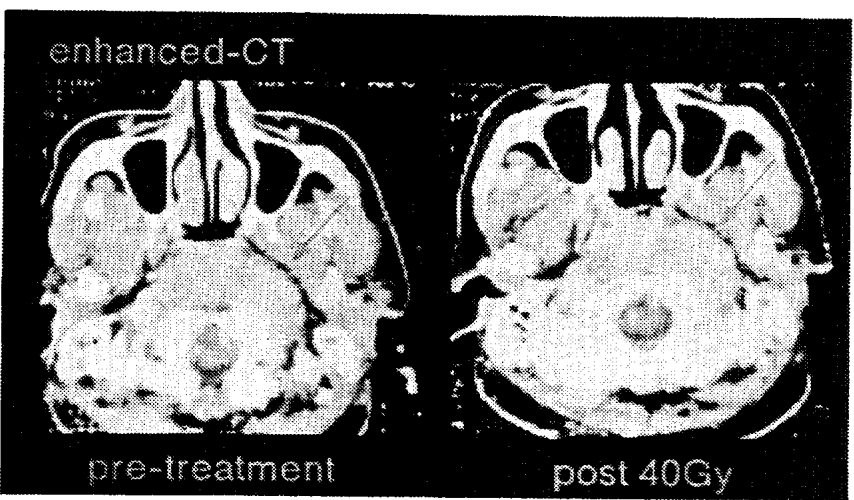

図 6. $40 \mathrm{~Gy}$ 照射治療前後の上咽頭癌 (矢印)のCT例. CT 画像 では著名な変化は見られない。

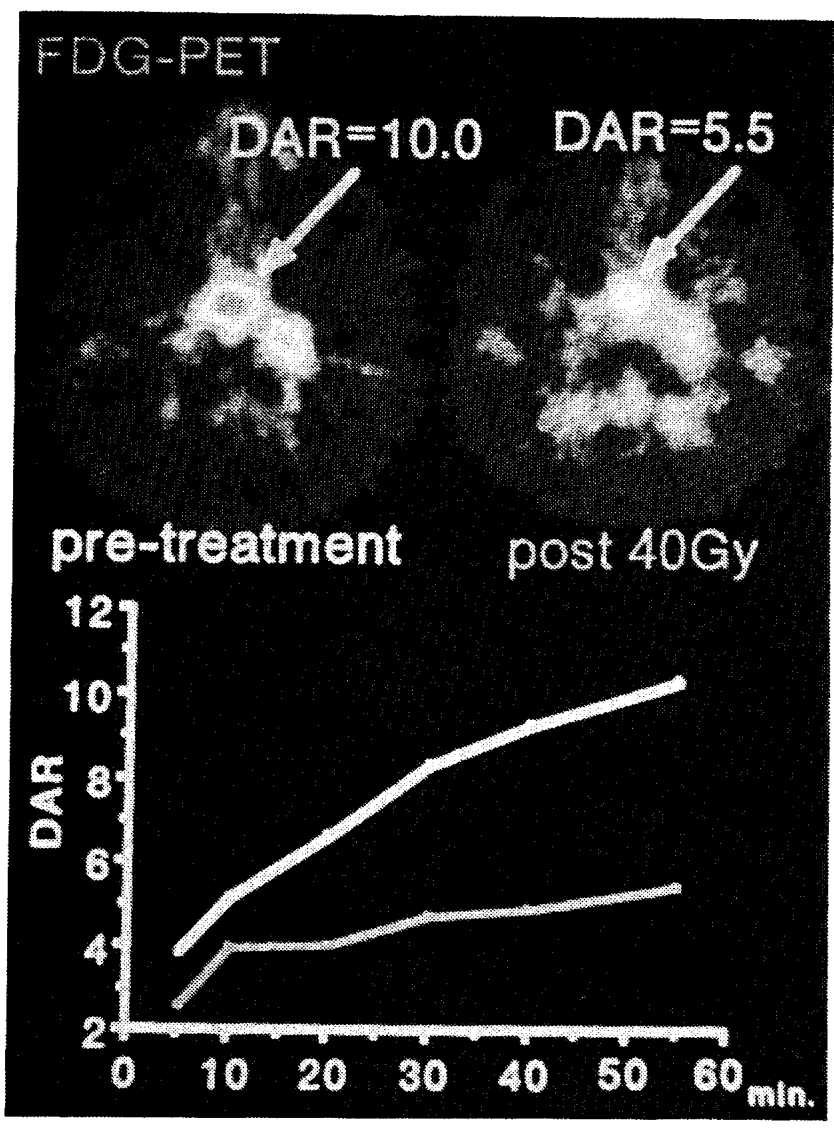

図 7. 前図と同症例のPET 画像. DAR は照射後減少L, TAC は上昇カーブから中等度カーブへと変化し, 治療効果 が明らかに認められる。

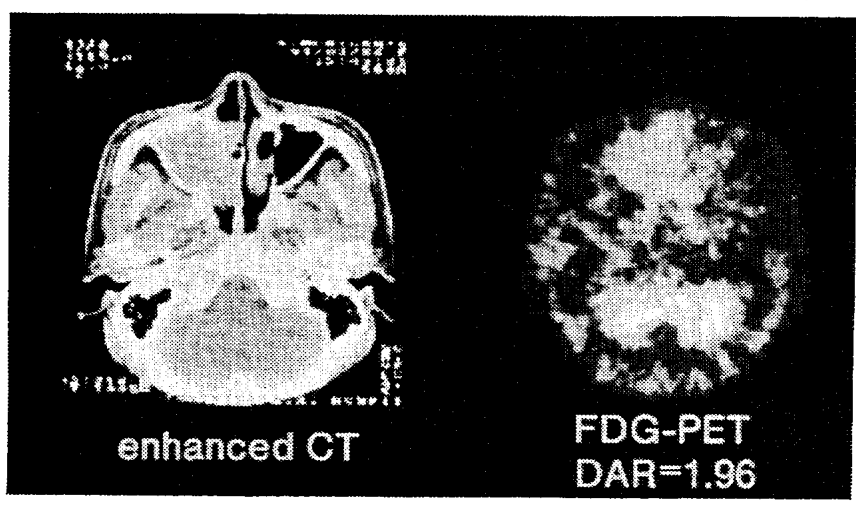

図 8. 鼻副鼻腔パピローマ症例. CT 像では悪性良性の鑑別 は困難であるが, PET像ではDAR1.96 と良性腫瘍と判 別できる。

\section{参 考 文 献}

1. 鳥塚莞爾監修: What is pet?"QandA”, $1 \sim 9$, 日本アイソ トープ協会医学 (1992)

2. Strauss, LG., Conti, PS.: The appliciations of PET in clinical oncology. J Nucl Med. 32(4) 623-648 (1991)

3. Wagner HN Jr., Conti PS : Advances in medical imaging for cancer diagnosis and treatment : Cancer, 67 :1121-1128 (1991) 
4. Di Chiro G., Oldtield E., Bairamian D. : In vivo glucose utilization of tumors of the brain stem and spinal cord. In : Greitz T. Ingvar DH., Widen L. (Eds) Positron emission tomography. New York : 351-361 Raven Press. (1985)

5. Woodard HQ., Gigler RE., Freed B., Russ G. : Expression of tissue isotope disribution. J Nucl Med. 16:958-959 (1975)

6. Okamura, T., Kawabe, J., Hosokawa, T., Kobashi, T., Simonishi, Y., Jomura, N., Ochi, H., Onoyama, Y., Sakamoto, H., Ohashi, Y., Nakai, Y. : FDG-PET studies of head and neck lesiens. Ochi, $\mathrm{H}$ et al (Eds) : Brain, heart and tumor imaging updated PET and MRI. 139-148 Elsevier Science (1995)

7. 中井義明：頭䅡部腫瘍に対する PET の臨床応用, 云門医 通信, $44: 12-13$ (1995)

8. 越智宏鴨：腫瘍 clinical PET, 免疫腫瘍核医学 10(1) 16-19 (1995)

9. 岡村光英, 河辺譲治, 小山孝一, 小橋孝子, 阪本浩一, 露 口尚弘, 城村尚登, 下西祥裕, 岸本健治, 山田龍作, 中井 義明, 越智弘鴨：頭䅡部腫瘍の FDG-PET における良悪性 鑑別。臨床放射線 41(12) 1487-1493 (1996)

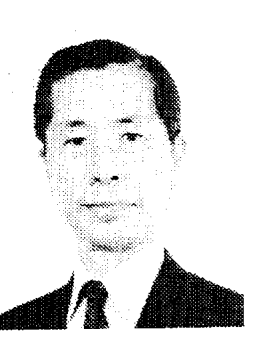

中井義明 (なかい よしあき)

昭和 33 年大阪市立大学医学部卒業. 昭和 38 年同医学部耳當咽喉科助手. 昭和 39 年 〜 42 年アメリカエール大学留学. 昭和 47 年講師. 昭和 52 年教授. 平成 8 年同大学 付属病院長.

第 30 回日本基礎耳科学会. 第 1, 2 回日 韓耳罳咽喉科頭頝部外科学会. 第 32 回日本オージオロジー学 会. 第 4 回日本耳科学会. 第 54 回日本平衡神経科学会. 第 48 回日本耳亩咽喉科学会, 各会長. 